\title{
Monetary Assessment of Restored Habitats as a Support Tool for Sustainable Landscape Management in Lowland Cultural Landscapes
}

\author{
Jan Brus ${ }^{1, * \mathbb{C}}$, Jan Deutscher ${ }^{2}{ }^{-}$, Aleš Bajer ${ }^{3}$, Petr Kupec ${ }^{2}$ and Lucie Olišarová ${ }^{2}$ \\ 1 Department of Geoinformatics, Palacký University Olomouc, 17. listopadu 50, \\ 77146 Olomouc, Czech Republic \\ 2 Department of Landscape Management, FFWT MENDELU, Zemědělská 1665/1, \\ 61300 Brno, Czech Republic; jan.deutscher@mendelu.cz (J.D.); pkupec@seznam.cz (P.K.); \\ lucie.olisarova@seznam.cz (L.O.) \\ 3 Department of Geology and Pedology, FFWT MENDELU, Zemědělská 1665/1, 61300 Brno, Czech Republic; \\ bajer@mendelu.cz \\ * Correspondence: jan.brus@upol.cz
}

Received: 30 December 2019; Accepted: 10 February 2020; Published: 12 February 2020

\begin{abstract}
Surfaces directly influenced by mining and post-mining have risen to prominence in the field of restoration ecology. It is important to gain a better understanding of sustainable landscape management in lowland European cultural landscapes. Sand and gravel-pit areas were selected as study sites, where mining activities have been the main factor in land use over recent decades. The post-mining restoration of each area disturbed by mining processes was planned according to legally enforced technical and biological restoration protocols, as well as a specific document entitled the Biological Action Plan (BAP). The financial costs of BAPs for individual study sites were compared with the monetary value of habitats over three time periods. The economic evaluation was based on the assessment method of ecological harm to habitats carried out in Hesse (Germany). The results show that the restoration of target habitats after mining will establish and gradually develop new natural habitats with a higher monetary value than before mining, which become refuges of biodiversity in cultural landscapes. The results also indicate that the ecological restoration of post-mining areas can result in a higher monetary value of the restored natural habitats in comparison to the original habitats which were destroyed by mining.
\end{abstract}

Keywords: monetary assessment; NATURA2000; mining sites; financial assessment

\section{Introduction}

European landscapes have been managed by humans for centuries. European lowland landscapes along large rivers have been modified through agricultural use on a local scale since the Neolithic period [1]. Regional land-use changes in many European lowland landscapes started in the early Middle Ages, when traditional cultural landscapes were being established [2]. The socio-economic development of each society, related to strengthening production and residential, administrative, and cultural-societal functions, results in ever-increasing pressures on ecosystems and their individual components. The cultural landscape is a representative picture of the state and the development of society [3]. Land-use changes in lowland European cultural landscapes were the main negative drivers that influenced both biodiversity [4] and the provision of ecosystem services [5,6]. Currently, the impact of land-use changes on ecosystems is accelerated by global climate change [7] and various other human activities, such as agricultural intensification [8], forest management [9], ecosystem fragmentation [10] and mining [11]. 
The increasing area of land surface directly influenced by mining and post-mining activities (i.e., the depositing of ash and waste [12]), has given rise to the development of restoration ecology [13,14]. The ecological restoration of ecosystems disturbed by mining is essential for the overall restoration and future sustainable maintenance of ecosystem functions in lowland cultural European landscapes. This topic is an important challenge for us to gain a better understanding of sustainable landscape management in lowland cultural European landscapes [15].

Fundamental ecological principles are important when applying restoration ecology to the management of disturbed landscapes, and these principles have been generally defined [16], but some knowledge gaps still exist in relation to many problems in the application of ecological restoration to sustainable landscape management. Ecological restoration supports an increase in biodiversity and other ecosystem services [17]. In current studies, the ecosystem services approach was used to assess the impacts of mining activities and post-mining restoration processes [18-20]. Following restoration, these areas can benefit mainly from biodiversity, water regulation or aesthetic and recreation.

Biodiversity is commonly used as a criterion of ecosystem health and of the success of ecological restoration or protection [21,22]. Nevertheless, biodiversity must be carefully considered on different levels as it can be misleading in restoration ecology practice [23]. Selecting the biodiversity of species as indicators of restoration projects in post-mining areas must be related to a special focus on aspects that can be managed according to the locality [24]. In addition to the issues already discussed, uncertainty is another critical issue facing the valuation of ecosystem services and biodiversity. Actual problems with assessing the ecosystems include the uncertainty associated with the classification of land cover classes, and the categorization process of biotopes themselves [25].

New insights into restoration ecology in cultural landscapes have brought about the economic assessment of ecosystem services [26], because an econometric estimation of biodiversity supports public awareness of the importance of restoration projects in a generally clear way [27]. The restoration targets in the ecological restoration of post-mining areas are partly dependent on the values of the local stakeholders. Thus, knowledge of the monetary value of ecosystems in is essential for sustainable landscape management planning and practice in cultural European landscapes [28]. We believe that the monetary assessment of both biodiversity and natural habitats can be considered as a key to the holistic evaluation of ecosystem services provided by restored ecosystems in mining areas. In this study, we aimed to evaluate the monetary value of habitats in three sandpit post-mining sites in lowland areas of the Czech Republic (Central Europe). We analyzed the differences in the monetary value of habitats before and after sand mining. We used an original, expert method [29] which has been widely used in the monetary assessment of natural habitats [30]. The aim of our study was to test a hypothesis based on the general assumption that mining activities decrease the monetary value of habitats in mining areas.

\section{Study area and Methods}

All the study sites in this study (Figure 1) are sand and gravel-pit areas, where mining activities have been the main force in land use over recent decades. The post-mining restoration of each area disturbed by mining processes was planned according to legally enforced technical and biological restoration protocols as well as the specific document entitled the Biological Action Plan (BAP). The Biodiversity Action Plan is a specific approach adopted by the mining company responsible for mining activities in these areas, with the aim to ensure ecological stability and the sustainable utilization of their post-mining sites [31]. The aim of the BAP is to provide support for the decision-making process and to encourage the implementation of effective management measures aimed at conserving and enhancing the biodiversity of the target areas, whilst also taking into account the ongoing technical and biological restoration legislation imposed by Czech mining law. At the same time, it also incorporates other landscape uses (recreation, agriculture, stakeholder visions, etc.) to ensure the long-term sustainability of the areas. 


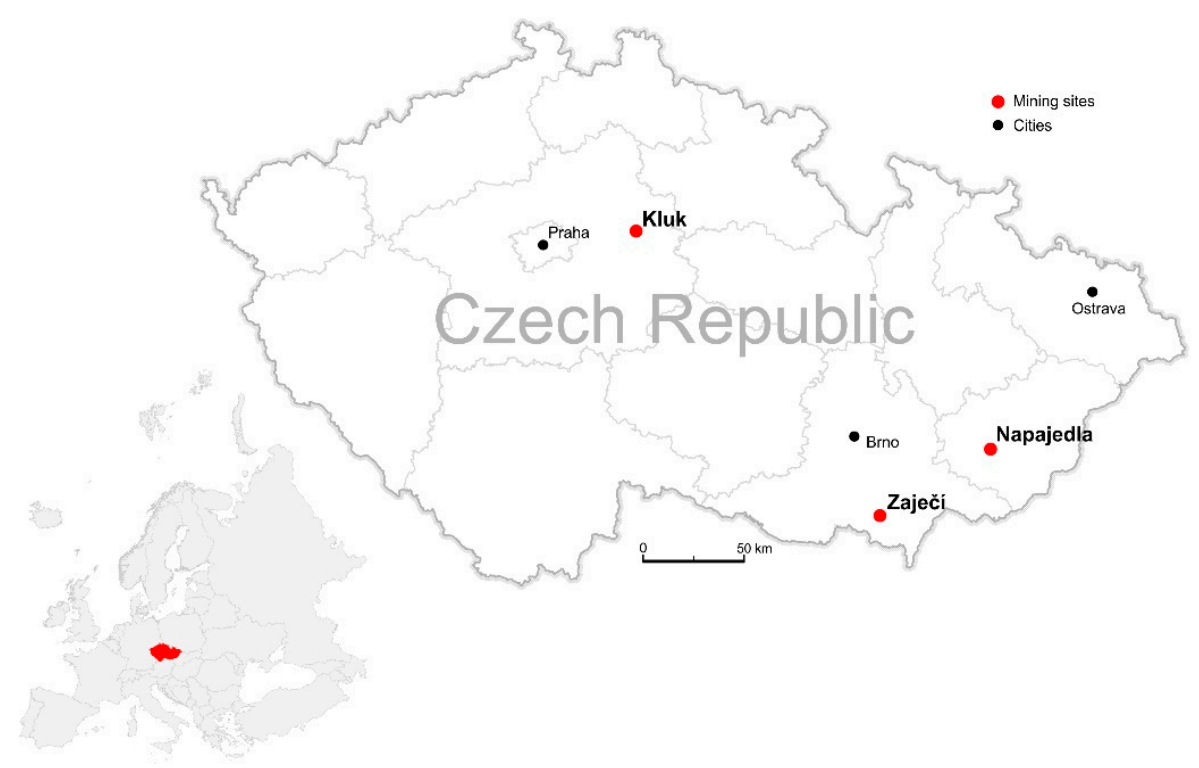

Figure 1. Localization of study sites.

In the BAP, "target biotopes" are defined for the locality according to the NATURA 2000 systemization [32]. For these target biotopes, specific management measures for five years ahead are planned, and these incorporate the ecological and ethological demands of the expected important species which will inhabit them. The total financial cost of the designed measures is then calculated according to national standardized costs. In this way, the document offers a basic idea of the expected financial cost, the work involved and the duration of the initial restoration process.

\subsection{Kluk Study Site}

The mining site Kluk is located in the Elbe lowlands. It can be characterized as a floodplain area with flat morphology that originated from the erosive and sedimentation activities of the river Elbe and its tributaries. The geology consists of alluvial quaternary sediments in the form of gravel and sand from the river terrace, with enclaves of eolic loess and loam on the slopes of the surrounding hills. The area has interesting hydrogeology of cretaceous sea sediments with the occurrence of both permeable sandy sites (collectors) and marl and clay sites (isolators). In the studied locality, two different collectors of groundwater can be distinguished: a subsurface collector of quarterly sand and gravel sediments directly communicating with the river Elbe, and a deep underground collector of older waters accumulated in the cretaceous sandy sediments (local mineral water Podebradka). The soils in the area are relatively homogeneous with two main soil types: fluvisols and gleysols. The climate is warm relative to the other areas-one of the hottest in the Czech Republic with a mean annual temperature around $9{ }^{\circ} \mathrm{C}$ and with mean annual precipitation around $600 \mathrm{~mm}$. The mining site is located on the borders of a Special Area of Conservation, Natura 2000 (SAC Libicke luhy). The vegetation can be characterized as a mosaic of floodplain forests and semi-natural cultivated meadows. The cultivated meadows are the result of the traditional management of cutting grass for bedding and food for livestock; a practice that has been abandoned for the most part in recent years. The semi-natural biotopes consist of the typical remnants of continental meadows and fragments of sedge meadows that form the local monocenosis.

Mining in this area has a long history. Up until 1976, mining was done in one lake in the northern parts of the mining site. In the following years, mining was extended, and more lakes were formed. There are five lakes currently. Before the mining started, the area was a mosaic of biotopes (Table A1, such as extensively managed fields of arable land and cultural meadows, semi-natural meadows and remnants of floodplain forests. The study areas where BAP was prepared covers the fifth post-mining 
lake and its close surroundings. Mining is not completely finished in the southern parts of the lake. However, technical restoration has already taken place on most of the other banks. According to a zoological survey, no critically endangered species were present in the locality. The highest ecological value is now present in the restored banks of the lake, both with vertical and gradual slopes, as they offer potential habitats for a several of specially protected amphibian species (Bombina bombina, Hyla arborea, Rana dalmatina) that occur in the Libicke luhy SAC. Close to the lake's banks, there are still fragments of undamaged sedge meadows that could function as seed banks for the successful natural ecological restoration of neighboring sites designated for restoration.

The technical restoration consisted of stabilizing the lake banks, creating a littoral zone and soil conditioning on certain sites (adding a layer of topsoil rich with organic matter on the worst damaged areas). The banks beneath the expected water surface were shaped into a slope of 1:3.5 that, according to the soil characteristics, should ensure long-term stability. Some were left untouched in a vertical slope for natural abrasion processes to take place. The southern banks were shaped into gradual slopes of 1:10 to 1:15 by unsaleable fractions of sand and waste material from the mining. The bottom was shaped into a complex of different depths with humps and depressions to ensure a wider range of water habitats. The areas indirectly affected by mining such as manipulation sites, conveyor belt emplacements, associated areas, etc., were conditioned by a cover of humic topsoil $15 \mathrm{~cm}$ deep. The following biological restoration will consist mainly of the establishment of vegetated areas; woody sections and plant meadows.

According to the BAP, in five years the following target biotopes should be present in the locality: rich mesotrophic meadow, initial oligotrophic meadow, green vertical banks, green gradual banks, and reed. To reach the desired status, state-specific management measures were planned in the BAP (Table A1). During the mining process, the soils were either removed or the topsoil was heavily damaged by the transportation and mechanization and following quick nutrient leaching. This was reflected in the target biotopes, as most of them could be characterized as early succession or naturally oligotrophic ecosystems. Therefore, the management measures were primarily designed to streamline the natural ecological succession (such as the removal of ruderal vegetation and invasive species) with the utilization of the seed bank of naturally more stable neighboring biotopes from the Libicke luhy SAC and to keep the low nutrient content and to protect against eutrophication (regular mowing, including disposal of mown material).

\subsection{Zajeci Study Site}

The mining site Zajeci is located in the floodplain of the river Dyje on the south-eastern border of the Dyje-Svratka valley. The area is characterized by a wide river valley bounded from the North by older river terraces and neogenic sediments originating in the Dyje-Moravian hills. It is one of the hottest areas in the Czech Republic (mean annual temperature approaching $10^{\circ} \mathrm{C}$ ) with a mean annual rainfall of around $500 \mathrm{~mm}$. The winds blow most of the year in a westerly or north-westerly direction; they carry dry air and cause desiccation. In recent decades, the local climate has been altered by a big artificial water body known as the Novomlynsky reservoirs. The soils in the floodplain are a mosaic of fluvisols, characterized by the alternation of different soil types (from alluvial coherent clay to permeable sand and gravel terraces). In the distant parts of the floodplain and the surrounding mild slopes, weathered sandy loam can often be found covered by overlays of loess sediments. On the loess sediments, a typical mosaic of fertile black and brown soils is formed. The evolution of natural biotopes is highly dependable on the water table level. The active mining of sandy gravel in close vicinity to the river channel and its natural deepening considerably decreases the water table level in the study area. Therefore, the current potential vegetation is mostly woody steppe with small enclaves of floodplain forest in local depressions. The biggest threats to these biotopes come in the form of invasive species such as acacia (Robinia pseudoacacia) and bush grass (Calamagrostis epigejos), eutrophication and following ruderalization. 
Mining in the area dates back to many decades ago. In 1987, an old post-mining lake with an area around 1ha was located there. The modern mining era began in 1989 with a new mining permit. The studied area where the BAP was prepared is located in the eastern part of the mining site, around a new post-mining lake and its surroundings. Here, mining started in 2012. Up to that point, the locality was part of a huge block of arable land and, as such, it was intensively managed for plant production (Table A2). The targeted materials here were gravel and sand, and they were extracted from the open cast mine. Due to the vicinity of the Dyje River and the high-water table, a lake formed after the extraction of the mining material. Currently (in 2019), mining is finished, and technical restoration is in progress. In the current state, the highest biological value can be assigned to spatially minor biotopes along the ragged shoreline of the post-mining lake and the waterlogged depressions formed on flat sandy littoral zones and beneath the vertical abrasion cliffs. These habitats have almost disappeared from the Czech landscape due to river straightening and stabilization [33].

The technical restoration consisted of the construction and stabilization of the lake banks in required slopes with the use of overburden material. The northern banks were modelled into three small peninsulas with steep slopes (1:2). The rest of the banks were modelled into changing slopes from 1:11 to 1:2. The peninsulas and parts of the lower slope banks were also overlaid by cultural topsoil. The following biological restoration consisted mainly of the establishment of vegetated areas; woody sections and plant meadows. Grass cover was sown on all flat areas; whereas steep slopes and littoral zones had no topsoil added and were left to natural ecological succession.

According to the BAP, in five years the following target biotopes should be present in the locality: woody steppe, green vertical banks, green gradual banks and open water bodies. To reach the desired status, state-specific management measures were planned in the BAP (Table A2). Most of the target biotopes could be characterized by early succession or low nutrient content. Therefore, the management measures are primarily designed to streamline the ecological succession (such as the removal of ruderal vegetation and invasive species) and to keep a low nutrient content and protect against eutrophication (regular movement, including disposal of mown material).

\subsection{Napajedla Study Site}

The mining site is situated on the northern border between the South-Moravian floodplain and the Carpathian uplands. The area is characterized by the wide floodplain of the River Morava and is in one of the hottest parts of the Czech Republic (mean annual temperature approaching $10^{\circ} \mathrm{C}$ ) with slightly increased annual precipitation caused by the vicinity of the Vizovice uplands (mean annual precipitation around $500 \mathrm{~mm}$ ). Winds blow mostly in a northerly or north westerly direction and they carry dry air and cause desiccation. The typical mosaic of floodplain fluvisols is characterized by the occurrence of different soil types (from coherent clay to permeable sands and gravel). The evolution of biotopes is highly dependable on the water table level. The active mining of sandy gravel in close vicinity to the river channel and its natural deepening have considerably decreased the water table level in the study area. Consequently, the current natural biotopes can mostly be described as woody steppe and mesotrophic grassland, both of which are threatened by invasive ruderal species such as acacia (Robinia pseudoacacia) and bush grass (Calamagrostis epigejos).

The study area consists of the northernmost post-mining lake and its surroundings in the northern part of the mining site. Before mining started in 2009, this locality was part of a huge block of arable land and, as such, it was intensively managed for plant production (Table A3). The targeted materials here were gravel and sand and they were extracted from an open cast mine. Due to the vicinity of the Morava River and the high-water table, a lake formed after the extraction of the mining material and overburden. Currently (in 2019), mining has finished and the technical and following biological restorations are taking place. The highest biological value can be assigned to spatially minor biotopes along the rugged shoreline of post-mining lakes and waterlogged depressions formed either by flat sandy littoral zones or by steep vertical abrasion cliff sides. These kinds of biotopes have almost disappeared from the Czech landscape due to river straightening and stabilization. 
The technical restoration mainly consists of the construction and stabilization of the lake banks in required slopes, the stabilization of the overburden at chosen sites and the overlay of some parts of the site by cultural topsoil. The following biological restoration mainly consists of the establishment of vegetated areas; woody sections and plant meadows.

According to the BAP, in five years the following target biotopes should be present in the locality: green vertical banks, extensive orchards, woody steppes, green gradual banks, rich mesotrophic meadow, open water bodies, green vertical banks and meadow beach. To reach the desired status, state-specific management measures were planned in the BAP (Table A3). Most of the target biotopes could be characterized as early succession or low nutrient content. Therefore, the management measures are primarily designed to streamline ecological succession (such as the removal of ruderal vegetation or invasive species) or to keep the low nutrient content and protect against eutrophication (regular moving including disposal of the mown material).

\subsection{Methods of Monetary Assessment of Habitats}

The financial costs of BAPs for individual study sites were compared with the monetary value of habitats at each site over three time periods: Before the start of mining activities, the current state and the target habitats after restoration. The biotopes were identified based on catalog of habitats in the Czech Republic, which is based on detailed terrain research done between 2001 and 2004 in order to create a network of the areas of European importance [32].

Economic assessment of the landscape draws on a modified Hessen biotope assessment method adjusted to the conditions of the Czech Republic [29]. Its detailed description which we followed was published in previous studies [30,34]. The method is based on a national list of habitat types and an expert evaluation of their point value (PV) in eight elementary evaluations of ecological criteria (matureness, naturalness, diversity of plant species, diversity of animal species, rareness of biotope, rareness of species, vulnerability, and threat to existence). A complete list of biotopes' point values is available at http://fzp.ujep.cz/projekty/bvm/bvm.pdf. For a specific type of habitat, the result of the point evaluation (related to 1 square meter of the habitat area) represents the relative ecological value of a specific habitat type in comparison with other habitat types. The final monetary value of an individual point for the Czech Republic amounted to EUR 0.592 in 2019.

\section{Results}

The results at each study site (Tables 1-3) did not support the hypotheses being tested: mining activities decrease the monetary value of habitats in mining areas even after their restoration. At the study site Kluk, there was a very diverse spectrum of natural habitats (including habitat reed beds of eutrophic still waters, habitat mesic meadows and habitat of floodplain forest) before the start of mining activities (Table 1). After restoration, all these former habitats will be restored as target habitats in the post-mining area. The results of analyze (Table 1) reveal that the monetary value of target habitats after restoration will be increased by $18 \%$ in comparison to the monetary value of habitats before mining. 
Table 1. Biotope value in the locality Kluk.

\begin{tabular}{|c|c|c|c|}
\hline & Biotope (Natura 2000) & Area $\left(\mathrm{m}^{2}\right)$ & Value CZK \\
\hline \multirow{28}{*}{ Before } & X3 (100) & 1186 & 216896 \\
\hline & $\mathrm{T} 1.1(100)$ & 8800 & 4425696 \\
\hline & $\mathrm{T} 1.7(100)$ & 10,133 & 10192177 \\
\hline & T1.1 (100) & 3401 & 1710431 \\
\hline & M1.7 (100) & 12,396 & 4911791 \\
\hline & X3 (100) & 32,541 & 5951098 \\
\hline & M1.7 (100) & 10,830 & 4291279 \\
\hline & M1.1 (100) & 5049 & 2154509 \\
\hline & L3.1 (100) & 1354 & 969843 \\
\hline & M1.7 (100) & 5486 & 2173773 \\
\hline & $\mathrm{T} 1.7(100)$ & 10,881 & 10944545 \\
\hline & M1.1 (100) & 5054 & 2156642 \\
\hline & L2.3B (100) & 335 & 255270 \\
\hline & K1 (20), M1.1 (40), M1.7 (40) & 512 & 218481 \\
\hline & $\mathrm{T} 1.1(100)$ & 947 & 476265 \\
\hline & K1 (100) & 1851 & 1015533 \\
\hline & M1.1 (100) & 967 & 412638 \\
\hline & T1.1 (30), T1.9 (70) & 8651 & 7119427 \\
\hline & T1.1 (50), T1.4 (50) & 19,640 & 11822887 \\
\hline & X3 (100) & 17,673 & 3232038 \\
\hline & T1.1 (100) & 9740 & 4898441 \\
\hline & X14 (100) & 12 & 2743 \\
\hline & M1.7 (100) & 218 & 86380 \\
\hline & T1.4 (100) & 9631 & 6751716 \\
\hline & M1.1 (100) & 18,541 & 7911816 \\
\hline & T1.1 (40), T1.4 (30), T1.9 (30) & 6723 & 4702846 \\
\hline & L2.3B (80), M1.7 (20) & 3893 & 2681685 \\
\hline & Total & 206,445 & 101686846 \\
\hline \multirow{12}{*}{ Current state } & X7A 50, M1.1. 50 & 2748 & 942289 \\
\hline & X7A 50, M1.1. 50 & 9426 & 3232175 \\
\hline & X7A 30, T1.1. 40, M1.7. 30 & 1407 & 559654 \\
\hline & X7A 50, M1.1. 50 & 6833 & 2343036 \\
\hline & X6 70, T1.1. 20, M1.7. 10 & 10,312 & 2875934 \\
\hline & $\mathrm{X} 6$ & 1500 & 297180 \\
\hline & X7A 30, T1.1. 40, M1.7. 30 & 36,422 & 14487360 \\
\hline & X7A 30, T1.1. 40, M1.7. 30 & 19,180 & 7629114 \\
\hline & X7A 50, M1.1. 50 & 10,731 & 3679660 \\
\hline & $\mathrm{X} 14$ & 91,124 & 20830946 \\
\hline & X14 & 6483 & 1482014 \\
\hline & Total & 206,445 & 58359363 \\
\hline \multirow{13}{*}{ Target biotopes } & M1.1 & 2748 & 1172627 \\
\hline & M1.1 & 9426 & 4022263 \\
\hline & M1.1. 80, T1.7. 20 & 1407 & 763359 \\
\hline & M1.1 & 6833 & 2915778 \\
\hline & T1.1. 50, M1.7. 50 & 10,312 & 4636069 \\
\hline & M2.3. 80, L2.2. 10, M1.1. 10 & 1500 & 1019556 \\
\hline & M1.1. 80, T1.7. 20 & 36,422 & 19760538 \\
\hline & M1.1. 80, T1.7. 20 & 19,180 & 10405994 \\
\hline & M1.1 & 10,731 & 4579132 \\
\hline & $\mathrm{V} 1$ & 91,124 & 65270299 \\
\hline & L2.2. 60, M2.3. 20, M1.1. 20 & 6483 & 3971797 \\
\hline & T1.1. 50, M1.7. 50 & 10,279 & 4621233 \\
\hline & Total & 206,445 & 123138645 \\
\hline
\end{tabular}

The column Biotope (Natura 2000) contains abbreviations describing the corresponding biotopes according to the national nomenclature of the Natura 2000 Biotopes [32]. The basic description of the so-called formation groups are as follows: $\mathrm{X}$-Anthropogenic or heavily man-influenced biotopes; T-Secondary grasslands and heaths; $\mathrm{M}$-Wetlands and coastal vegetation; L-Forests; $\mathrm{K}-\mathrm{S}$ crublands; $\mathrm{V}$-Watercourses and water bodies. If numbers are present at the end of the description, for example, X7A 50, M1.1. 50, it corresponds to a mosaic of biotopes with an areal representation of $50 \%$ and $50 \%$. 
Table 2. Biotope value in the locality Zaječí.

\begin{tabular}{cccc}
\hline & Biotope (Natura 2000) & Area $\mathbf{( m}^{\mathbf{2}}$ ) & Value CZK \\
\hline \multirow{2}{*}{ Before } & 211 & 121,005 & 19916455 \\
& Total & $\mathbf{1 2 1 , 0 0 5}$ & $\mathbf{1 9 9 1 6 4 5 5}$ \\
\hline \multirow{5}{*}{ Current state } & X14 & 86,658 & 19810019 \\
& X14 & 1193 & 272720 \\
& X6 & 5607 & 1110859 \\
& X6 & 27,547 & 5457612 \\
Target biotopes & Total & $\mathbf{1 2 1 , 0 0 5}$ & $\mathbf{2 6 6 5 1 2 1 0}$ \\
& M1.1 50, M2.3. 50 & 1193 & 681800 \\
& V1 & 86,658 & 62071392 \\
& M2.3 & 5607 & 4016182 \\
& T1.1. 60, K3 40 & 27,547 & 13853937 \\
& Total & $\mathbf{1 2 1 , 0 0 5}$ & $\mathbf{8 0 6 2 3 3 1 1}$
\end{tabular}

The column Biotope (Natura 2000) contains abbreviations describing the corresponding biotopes according to national nomenclature of the Natura 2000 Biotopes [32].

Table 3. Biotope value in the locality Napajedla.

\begin{tabular}{cccc}
\hline & Biotope (Natura 2000) & Area $\mathbf{( m}^{\mathbf{2}}$ ) & Value CZK \\
\hline \multirow{3}{*}{ Before } & 211 & 242,205 & 39865005 \\
& 231 & 189 & 38021 \\
Total & $\mathbf{2 4 2 , 3 9 4}$ & $\mathbf{3 9 9 0 3 0 2 6}$ \\
\hline X14 & 5434 & 1242212 \\
Current state & X6 & 1194 & 236555 \\
& X7A 50, X6 30, L2.2. 20 & 67,535 & 21408055 \\
X6 70, X7A 30 & 6632 & 1435218 \\
& X7A & 3906 & 1011966 \\
& X14 & 136,336 & 31166410 \\
& X6 80, X7A20 & 19,599 & 4121905 \\
Total & $\mathbf{2 4 2 , 3 9 4}$ & $\mathbf{6 0 6 2 2 3 2 1}$ \\
\hline M1.1 50, M2.3 50 & 5434 & 3105531 \\
T1.1. 80, X3 20 & 1194 & 534979 \\
& T1.150, K3 30, L2.2 20 & 67,535 & 35817322 \\
& M2.3 & 6632 & 4750369 \\
T1.1. & 3906 & 1964406 \\
V1 & 136,336 & 97654750 \\
& M1.1 50, M2.3 50 & 1758 & 1004697 \\
X7A 60, T1.1 40 & 19,599 & 6989317 \\
Total & $\mathbf{2 4 2 , 3 9 4}$ & $\mathbf{1 5 1 8 2 1 3 7 1}$ \\
\hline
\end{tabular}

The column Biotope (Natura 2000) contains abbreviations describing the corresponding biotopes according to national nomenclature of the Natura 2000 Biotopes [32].

The results from the study site Zajeci indicated the same trend, but more significantly: Before the start of mining there were only anthropogenic habitats in the study area (Dominated by arable land and with an absence of natural habitats). After restoration, the restored post-mining area will be covered by a mosaic of natural habitats (reed beds of eutrophic still waters, the vegetation of exposed bottoms in warm areas, macrophyte vegetation of eutrophic still waters, mesic meadows, and willow scrub). The increase in the monetary value of habitats in this study area will reach $400 \%$ of the former monetary value (Table 2).

Very similar results were identified at the study site Napajedla (Table 3), where the increase in the monetary value of the habitat will reach $380 \%$ of the habitat's monetary value before the start of mining. After restoration, the target habitats in this study site will contain the same habitat types as the study site Kluk (compare Tables 1 and 3). Generally, in the three study sites, we identified similar trends: If the site was originally located on arable land, the mining process and the creation of artificial lakes 
already increased the monetary value of the biotopes compared to its initial value (Zaječí, Napajedla). In all cases, the restoration of target habitats after mining has the potential to establish and gradually develop new natural habitats with a higher monetary value than before mining.

\section{Discussion}

Mining poses serious and highly specific threats to biodiversity [18]. Following this statement, we supposed that mining activities will lead to decreasing biodiversity and primarily expected that the monetary value of biotopes would be decreased. The results of this study indicated a higher monetary value for habitats in sandpit areas after the restoration of habitats following the end of mining activities in comparison with the monetary value of habitats before mining occurred (Tables 1-3). This result can be explained because of the strict application of the principles of restoration ecology during the planning of restoration measures. In all study sites, the target of the restoration (exactly planned in the frame of Biological Action Plans) was to establish natural habitats with high biodiversity. The habitats in study sites that were destroyed by the excavation of sand were habitats with low biodiversity, and there were other habitats strongly altered by human activities (such as arable land). This is a clear explanation for the results of this study.

The results of this study cannot be generalized, because in Central Europe, technocratic approaches still prevail in the restoration of land degraded by mining, and the application of ecological principles to restoration projects has been rare [35]. Moreover, it is necessary to mention that restoration heavily depends on successfully documenting the 'restored' status of the biotopes with biological surveys or other monitoring methods over the long-term period. Furthermore, the monitoring methods used can have strong impact on the results. Even though the present method is widely accepted, there exist several other techniques which can bring other results, as recent academic and policy debates have highlighted a wider range of values (e.g., relational and intrinsic values), valuation methods (e.g., socio-cultural methods), and worldviews (e.g., indigenous and local knowledge (ILK) systems) [36].

Considering the results, we believe that five years of ecosystem management is needed to achieve the target habitats in restored study sites. Some types of restored habitats (e.g., Mesic meadows) will need management in order to maintain their biodiversity according to the basic characteristics of habitat type in the Natura 2000 habitat classification [37]. The target of establishing and maintaining open grassland habitats is also limited by the possibility of an invasion by an alien species, such as Calamagrostis epigejos, which can form a dense and very compact sward, and prevent the establishment of a grassland habitat. Thus, we believe that the management of grassland habitats is necessary for long-term sustainability. The sustainable management of natural habitats which depend on human activities - such as the mowing of meadows - will be a very important factor in the effectiveness of conservation efforts and the maintenance of biodiversity in study sites. Spontaneous succession, in many large, disturbed and abandoned areas in this region, represents an interesting challenge in applying an ecological approach to future restoration in order to support biodiversity conservation [38] and ecosystem management should be an integral part of the ecosystem restoration process [39].

Some other target natural habitats (e.g., Willow scrub), which do not need management in order to be maintained in the long term, will be left to spontaneous vegetation succession. As mentioned above, spontaneous succession is currently considered to be a very useful tool in the restoration of areas disturbed by mining [40], including sandpits [41]. The authors of the study [42] found the highest cover of woody species in a sandpit - the wood succession ended in a sandpit close to the woods. This is in accordance with some of the targets (related to target forest habitats) of the restoration project in each of three sandpit areas in this study. In the succession of woody species, a whole array of different factors play important roles $[43,44]$. Thus, applying succession to restoration projects involves the manipulation of succession.

The restoration targets in the successful application of the principles of restoration ecology in disturbed areas need a definition of biodiversity indicators, although a consensus on a definition is difficult due to the complexity of biodiversity and local conditions [45]. We used the characteristics of the 
target habitats as described in the Czech national catalog of habitats under the Natura 2000 network [46]. The restoration targets are usually on a local scale and influenced by local stakeholders—who may be interested in the economic aspects of a restoration project. Information related to the monetary value of restored habitats (in comparison to the former state of the study areas before mining) can be important in raising the awareness of restoration targets. The monetary estimation of habitats can support the targets of restoration. Thus, this information can be considered as a decision support tool for both stakeholders and decision-makers in the frame of landscape management in cultural landscapes involving post-mining areas. We expect that the value of point value will be increased in time. This trend can be observed since 2003, when the point value was first determined. Possible negative influences on financial value can be determined by the material values placed by the stakeholders [47].

\section{Conclusions}

This study supports the emerging knowledge related to the ecological importance of post-mining areas as refuges of biodiversity in cultural landscapes. The study is in accordance with other studies and proved the importance of restoring areas affected by human activities. The results of the study indicate that the ecological restoration of post-mining areas (if the principles of restoration ecology have been applied) can result in a higher monetary value of the restored natural habitats in comparison to the original habitats which were destroyed by mining. We emphasized that these results cannot be generalized, and the interpretation is based on local conditions and the achievement of targets related to natural habitats. We also highlighted the importance of the management of the target open grassland habitats. Spontaneous succession must be involved in ecological restoration, especially if the target of restoration is a woodland habitat. For significant habitats corresponding to early succession stages (sandbanks, dry grasslands, oligotrophic wetlands), appropriate management should be ensured even after mining and recovery have been completed. Anthropogenic lakes created by gravel mining may be regionally important as a nesting place for water birds. Management interventions in favor of some vertebrate species also have a relatively good tradition in the Czech Republic. The sandpits were shown to be important for the regional persistence of some species, some of which were thought to be extinct in the Czech landscape [48].

Ecological restoration aims to recreate, initiate, or accelerate the recovery of an ecosystem that has been disturbed. There are many examples in which mined land has been effectively rehabilitated for agricultural, forestry, conservational, urban or industrial land uses [49]. From this perspective, it is important to restore old mining places. Targeted recovery, to increase biodiversity and exploit the full potential that the mining landscape can offer, is very meaningful. Well-managed restoration can contribute to enhancing biodiversity, but also to enhancing the recreational and aesthetic function of the landscape.

This study suggested some implications for sustainable landscape management in cultural landscapes. A comparison of the monetary value of habitats disturbed by mining and the monetary value of restored habitats is important for the successful achievement of restoration targets and, more generally, it can be used as a decision support tool for sustainable landscape management in cultural landscapes.

Author Contributions: Conceptualization, J.B., J.D. and A.B.; Methodology, J.B., J.D. and P.K.; Investigation, J.D., P.K., L.O. and A.B..; Data Curation, J.D., L.O. and J.B.; Writing-Original Draft Preparation, J.B., J.D., A.B. and P.K.; Visualization, J.B.; Supervision, J.B., J.D., A.B., P.K., Writing-review and editing, J.B., J.D., L.O. All authors have read and agreed to the published version of the manuscript.

Funding: This research was funded by project Significant Trees-Living Symbols of National and Cultural Identity DG18P02OVV027 financed by Ministry of Culture Czech Republic.

Acknowledgments: Authors would like to thank for the support by institutional plan of MENDELU 2019-2020 by strengthening and development of inventive activities at the FFWT MENDELU by creating of post-doc positions.

Conflicts of Interest: The authors declare no conflict of interest. 


\section{Appendix A}

Table A1. Biotope value in the locality Kluk.

\begin{tabular}{|c|c|c|c|c|c|c|}
\hline & $\begin{array}{c}\text { Biotope (Natura } \\
2000)\end{array}$ & Area $\left(\mathrm{m}^{2}\right)$ & Description & $\begin{array}{c}\text { Point } \\
\text { value } / \mathrm{m}^{2}\end{array}$ & Value CZK & $\begin{array}{c}\text { Value EUR (25.57 } \\
\text { CZK) }\end{array}$ \\
\hline \multirow{28}{*}{ Before mining } & X3 (100) & 1186 & cultural meadows & 12 & 216896 & 8459 \\
\hline & T1.1 (100) & 8800 & $\begin{array}{c}\text { continental } \\
\text { meadows }\end{array}$ & 33 & 4425696 & 172602 \\
\hline & T1.7 (100) & 10,133 & $\begin{array}{l}\text { continental } \\
\text { meadows }\end{array}$ & 66 & 10192177 & 397495 \\
\hline & T1.1 (100) & 3401 & $\begin{array}{l}\text { continental } \\
\text { meadows }\end{array}$ & 33 & 1710431 & 66707 \\
\hline & M1.7 (100) & 12,396 & sedge meadows & 26 & 4911791 & 191560 \\
\hline & X3 (100) & 32,541 & cultural meadows & 12 & 5951098 & 232093 \\
\hline & M1.7 (100) & 10,830 & sedge meadows & 26 & 4291279 & 167360 \\
\hline & M1.1 (100) & 5049 & reed & 28 & 2154509 & 84026 \\
\hline & L3.1 (100) & 1354 & floodplain forest & 47 & 969843 & 37824 \\
\hline & M1.7 (100) & 5486 & sedge meadows & 26 & 2173773 & 84777 \\
\hline & $\mathrm{T} 1.7(100)$ & 10881 & $\begin{array}{l}\text { continental } \\
\text { meadows }\end{array}$ & 66 & 10944545 & 426837 \\
\hline & M1.1 (100) & 5054 & reed & 28 & 2156643 & 84109 \\
\hline & L2.3B (100) & 335 & floodplain forest & 50 & 255270 & 9956 \\
\hline & $\begin{array}{c}\text { K1 (20), M1.1 (40), } \\
\text { M1.7 (40) }\end{array}$ & 512 & woody meadows & 28 & 218481 & 8521 \\
\hline & T1.1 (100) & 947 & $\begin{array}{l}\text { rich mesotrophic } \\
\text { meadow }\end{array}$ & 33 & 476265 & 18574 \\
\hline & K1 (100) & 1851 & brushland & 36 & 1015533 & 39606 \\
\hline & M1.1 (100) & 967 & reed & 28 & 412638 & 16093 \\
\hline & T1.1 (30), T1.9 (70) & 8651 & $\begin{array}{l}\text { rich mesotrophic } \\
\text { meadow }\end{array}$ & 54 & 7119427 & 277658 \\
\hline & T1.1 (50), T1.4 (50) & 19,640 & $\begin{array}{l}\text { rich mesotrophic } \\
\text { meadow }\end{array}$ & 39.5 & 11822887 & 461093 \\
\hline & X3 (100) & 17,673 & cultural meadows & 12 & 3232038 & 126049 \\
\hline & T1.1 (100) & 9740 & $\begin{array}{l}\text { rich mesotrophic } \\
\text { meadow }\end{array}$ & 33 & 4898441 & 191039 \\
\hline & X14 (100) & 12 & ruderal water body & 15 & 2743 & 107 \\
\hline & M1.7 (100) & 218 & sedge meadows & 26 & 86380 & 3369 \\
\hline & T1.4 (100) & 9631 & $\begin{array}{l}\text { rich mesotrophic } \\
\text { meadow }\end{array}$ & 46 & 6751716 & 263317 \\
\hline & M1.1 (100) & 18,541 & reed & 28 & 7911816 & 308561 \\
\hline & $\begin{array}{c}\mathrm{T} 1.1(40), \mathrm{T} 1.4(30), \\
\mathrm{T} 1.9(30)\end{array}$ & 6723 & $\begin{array}{l}\text { rich mesotrophic } \\
\text { meadow }\end{array}$ & 45.9 & 4702846 & 183411 \\
\hline & $\begin{array}{c}\text { L2.3B (80), M1.7 } \\
(20)\end{array}$ & 3893 & floodplain forest & 45.2 & 2681685 & 104586 \\
\hline & Total & 206,445 & & & 101686847 & 3965787 \\
\hline \multirow{13}{*}{$\begin{array}{l}\text { Current state } \\
\text { after mining } \\
\quad(2019)\end{array}$} & X7A 50, M1.1. 50 & 2748 & reed & 22.5 & 942289 & 36749 \\
\hline & X7A 50, M1.1. 50 & 9426 & reed & 22.5 & 3232175 & 126055 \\
\hline & $\begin{array}{c}\text { X7A 30, T1.1. 40, } \\
\text { M1.7. } 30\end{array}$ & 1407 & meadows & 26.1 & 559654 & 21827 \\
\hline & X7A 50, M1.1. 50 & 6833 & reed & 22.5 & 2343036 & 91378 \\
\hline & $\begin{array}{c}\text { X6 70, T1.1. 20, } \\
\text { M1.7. } 10\end{array}$ & 10,312 & manipulation area & 18.3 & 2875934 & 112161 \\
\hline & $\mathrm{X} 6$ & 1500 & gradual banks & 13 & 297180 & 11590 \\
\hline & $\begin{array}{c}\text { X7A 30, T1.1. 40, } \\
\text { M1.7. } 30\end{array}$ & 36,422 & meadows & 26.1 & 14487360 & 565007 \\
\hline & $\begin{array}{c}\text { X7A 30, T1.1. 40, } \\
\text { M1.7. } 30\end{array}$ & 19,180 & meadows & 26.1 & 7629114 & 297535 \\
\hline & X7A 50, M1.1. 50 & 10731 & reed & 22.5 & 3679660 & 143507 \\
\hline & $\mathrm{X} 14$ & 91,124 & open water body & 15 & 20830946 & 812407 \\
\hline & $\mathrm{X} 14$ & 6483 & vertical banks & 15 & 1482014 & 57799 \\
\hline & $\begin{array}{l}\text { X6 70, T1.1. 20, } \\
\text { M1.7. } 10\end{array}$ & 10,279 & manipulation area & 18.3 & 2866731 & 111803 \\
\hline & Total & 206,445 & & & 61226093 & 2387818 \\
\hline
\end{tabular}


Table A1. Cont.

\begin{tabular}{|c|c|c|c|c|c|c|}
\hline & $\begin{array}{c}\text { Biotope (Natura } \\
\text { 2000) }\end{array}$ & Area $\left(m^{2}\right)$ & Description & $\begin{array}{c}\text { Point } \\
\text { value } / \mathrm{m}^{2}\end{array}$ & Value CZK & $\begin{array}{c}\text { Value EUR ( } 25.57 \\
\text { CZK) }\end{array}$ \\
\hline \multirow{13}{*}{$\begin{array}{c}\text { Target biotopes } \\
\text { according to } \\
\text { BAP in five } \\
\text { years }\end{array}$} & M1.1 & 2748 & reed & 28 & 1172627 & 45732 \\
\hline & M1.1 & 9426 & reed & 28 & 4022263 & 156868 \\
\hline & M1.1. 80, T1.7. 20 & 1407 & $\begin{array}{l}\text { rich mesotrophic } \\
\text { meadow }\end{array}$ & 35.6 & 763359 & 29771 \\
\hline & M1.1 & 6833 & reed & 28 & 2915778 & 113715 \\
\hline & T1.1. 50, M1.7. 50 & 10,312 & $\begin{array}{c}\text { initial oligotrophic } \\
\text { meadows }\end{array}$ & 29.5 & 4636069 & 180807 \\
\hline & $\begin{array}{c}\text { M2.3. 80, L2.2. 10, } \\
\text { M1.1. } 10\end{array}$ & 1500 & $\begin{array}{l}\text { vegetated gradual } \\
\text { banks }\end{array}$ & 44.6 & 1019556 & 39763 \\
\hline & M1.1. 80, T1.7. 20 & 36,422 & $\begin{array}{l}\text { rich mesotrophic } \\
\text { meadow }\end{array}$ & 35.6 & 19760538 & 770661 \\
\hline & M1.1. 80, T1.7. 20 & 19,180 & $\begin{array}{l}\text { rich mesotrophic } \\
\text { meadow }\end{array}$ & 35.6 & 10405994 & 405834 \\
\hline & M1.1 & 10731 & reed & 28 & 4579132 & 178586 \\
\hline & $\mathrm{V} 1$ & 91124 & open water body & 47 & 65270299 & 2545542 \\
\hline & $\begin{array}{c}\text { L2.2. } 60, \text { M2.3. 20, } \\
\text { M1.1. } 20\end{array}$ & 6483 & green vertical banks & 40.2 & 3971797 & 154900 \\
\hline & T1.1. 50, M1.7. 50 & 10,279 & $\begin{array}{l}\text { initial oligotrophic } \\
\text { meadows }\end{array}$ & 29.5 & 4621233 & 180228 \\
\hline & Total & 206,445 & & & 123138644 & 4802407 \\
\hline
\end{tabular}

The column Biotope (Natura 2000) contains abbreviations describing the corresponding biotopes according to the national nomenclature of the Natura 2000 Biotopes [32]. The basic description of the so-called formation groups are as follows: $\mathrm{X}$-Anthropogenic or heavily man-influenced biotopes; $\mathrm{T}$-Secondary grasslands and heaths; $\mathrm{M}$-Wetlands and coastal vegetation; $\mathrm{L}-$ Forests; $\mathrm{K}-\mathrm{S}$ crublands; $\mathrm{V}$-Watercourses and water bodies. If numbers are present at the end of the description, for example, X7A 50, M1.1. 50, it corresponds to a mosaic of biotopes with an areal representation of 50 and $50 \%$.

Table A2. Biotope value in the locality Zaječí.

\begin{tabular}{|c|c|c|c|c|c|c|}
\hline & $\begin{array}{c}\text { Biotope (Natura } \\
\text { 2000) }\end{array}$ & Area $\left(m^{2}\right)$ & Description & $\begin{array}{c}\text { Point } \\
\text { value } / \mathrm{m}^{2}\end{array}$ & Value CZK & $\begin{array}{c}\text { Value EUR ( } 25.57 \\
\text { CZK) }\end{array}$ \\
\hline \multirow{2}{*}{ Before mining } & 211 & 121,005 & arable land & 10.8 & 19916455 & 776742 \\
\hline & Total & 121,005 & & & 19916455 & 776742 \\
\hline \multirow{5}{*}{$\begin{array}{l}\text { Current state } \\
\text { after mining } \\
\qquad(2019)\end{array}$} & $\mathrm{X} 14$ & 86,658 & open water body & 15 & 19810019 & 772591 \\
\hline & $\mathrm{X} 14$ & 1193 & vertical banks & 15 & 272720 & 10636 \\
\hline & $\mathrm{X} 6$ & 5607 & gradual banks & 13 & 1110859 & 43323 \\
\hline & $\mathrm{X} 6$ & 27,547 & manipulation area & 13 & 5457612 & 212847 \\
\hline & Total & 121,005 & & & 26651209 & 1039397 \\
\hline \multirow{5}{*}{$\begin{array}{l}\text { Target biotopes } \\
\text { according to } \\
\text { BAP in five } \\
\text { years }\end{array}$} & M1.1 50, M2.3. 50 & 1193 & $\begin{array}{l}\text { vegetated vertical } \\
\text { banks }\end{array}$ & 37.5 & 681800 & 26590 \\
\hline & V1 & 86,658 & open water body & 47 & 62071392 & 2420784 \\
\hline & M2.3 & 5607 & $\begin{array}{c}\text { vegetated gradual } \\
\text { banks }\end{array}$ & 47 & 4016182 & 156631 \\
\hline & T1.1. 60, K3 40 & 27,547 & woody steppe & 33 & 13853937 & 540304 \\
\hline & Total & 121,005 & & & 80623311 & 3144309 \\
\hline
\end{tabular}

The column Biotope (Natura 2000) contains abbreviations describing the corresponding biotopes according to the national nomenclature of the Natura 2000 Biotopes [32]. 
Table A3. Biotope value in the locality Napajedla.

\begin{tabular}{|c|c|c|c|c|c|c|}
\hline & $\begin{array}{c}\text { Biotope (Natura } \\
2000)\end{array}$ & Area $\left(m^{2}\right)$ & Description & $\begin{array}{l}\text { Point value } \\
\qquad / \mathrm{m}^{2}\end{array}$ & Value CZK & $\begin{array}{c}\text { Value EUR (25.57 } \\
\text { CZK) }\end{array}$ \\
\hline \multirow{3}{*}{ Before mining } & 211 & 242,205 & arable land & 10.8 & 39865005 & 1554735 \\
\hline & 231 & 189 & arable land & 13.2 & 38021 & 1483 \\
\hline & Total & 242,394 & & 10.8 & 39903026 & 1556218 \\
\hline \multirow{9}{*}{$\begin{array}{l}\text { Current state } \\
\text { after mining } \\
\quad(2019)\end{array}$} & $\mathrm{X} 14$ & 5434 & vertical banks & 15 & 1242212 & 48446 \\
\hline & $\mathrm{x} 6$ & 1194 & manipulation area & 13 & 236555 & 9226 \\
\hline & $\begin{array}{l}\text { X7A } 50, \text { X6 30, } \\
\text { L2.2. } 20\end{array}$ & 67535 & associated area & 20.8 & 21408055 & 834914 \\
\hline & X6 70, X7A 30 & 6632 & gradual banks & 14.2 & 1435218 & 55973 \\
\hline & X7A & 3906 & technical peninsula & 17 & 1011966 & 39467 \\
\hline & $\mathrm{X} 14$ & 136,336 & open water body & 15 & 31166410 & 1215490 \\
\hline & $\mathrm{X} 14$ & 1758 & vertical banks & 15 & 401879 & 15673 \\
\hline & X6 80, X7A20 & 19,599 & sown gradual banks & 13.8 & 4121905 & 160754 \\
\hline & Total & 242,394 & & & 61024200 & 2379944 \\
\hline \multirow{9}{*}{$\begin{array}{l}\text { Target biotopes } \\
\text { according to } \\
\text { BAP in five } \\
\text { years }\end{array}$} & M1.1 50, M2.3 50 & 5434 & $\begin{array}{l}\text { vegetated vertical } \\
\text { banks }\end{array}$ & 37.5 & 3105531 & 121116 \\
\hline & T1.1. 80, X3 20 & 1194 & extensive orchard & 29.4 & 534979 & 20864 \\
\hline & $\begin{array}{l}\text { T1.1 50, K3 30, } \\
\text { L2.2 } 20\end{array}$ & 67,535 & woody steppe & 34.8 & 35817322 & 1396876 \\
\hline & M2.3 & 6632 & $\begin{array}{c}\text { vegetated gradual } \\
\text { banks }\end{array}$ & 47 & 4750369 & 185264 \\
\hline & T1.1. & 3906 & $\begin{array}{l}\text { rich mesothrophic } \\
\text { meadow }\end{array}$ & 33 & 1964406 & 76612 \\
\hline & V1 & 136,336 & open water body & 47 & 97654750 & 3808535 \\
\hline & M1.1 50, M2.3 50 & 1758 & $\begin{array}{l}\text { vegetated vertical } \\
\text { banks }\end{array}$ & 37.5 & 1004697 & 39183 \\
\hline & X7A 60, T1.1 40 & 19,599 & meadow beach & 23.4 & 6989317 & 272583 \\
\hline & Total & 242,394 & & & 151821371 & 5921033 \\
\hline
\end{tabular}

The column Biotope (Natura 2000) contains abbreviations describing the corresponding biotopes according to the national nomenclature of the Natura 2000 Biotopes [32].

\section{References}

1. Kilianova, H.; Pechanec, V.; Brus, J.; Kirchner, K.; Machar, I. Analysis of the development of land use in the Morava River floodplain, with special emphasis on the landscape matrix. Morav. Geogr. Rep. 2017, 25, 46-59. [CrossRef]

2. Simon, J.; Machar, I.; Bucek, A. Linking the historical research with the growth simulation model of hardwood floodplain forests. Pol. J. Ecol. 2014, 62, 273-288.

3. Farina, A. Landscape Ecology and the General Theory of Resources: Comparing Two Paradigms. J. Landsc. Ecol. 2011, 4, 18-29. [CrossRef]

4. Oprsal, Z.; Harmacek, J.; Pavlík, P.; Machar, I. What factors can influence the expansion of protected areas around the world in the context of international environmental and development goals. Probl. Ekorozw. 2018, 13, 145-157.

5. Harrison, P.; Berry, P.; Simpson, G.; Haslett, J.; Blicharska, M.; Bucur, M.; Dunford, R.; Egoh, B.; Garcia-Llorente, M.; Geamănă, N. Linkages between biodiversity attributes and ecosystem services: A systematic review. Ecosyst. Serv. 2014, 9, 191-203. [CrossRef]

6. Pechanec, V.; Vavra, A.; Hovorkova, M.; Brus, J.; Kilianova, H. Analyses of moisture parameters and biomass of vegetation cover in southeast Moravia. Int. J. Remote Sens. 2014, 35, 967-987. [CrossRef]

7. Machar, I.; Vozenilek, V.; Kirchner, K.; Vlckova, V.; Bucek, A. Biogeographic model of climate conditions for vegetation zones in Czechia. Geogr. Prague 2017, 122, 64-82. [CrossRef]

8. Sklenicka, P.; Zouhar, J.; Trpáková, I.; Vlasák, J. Trends in land ownership fragmentation during the last 230 years in Czechia, and a projection of future developments. Land Use Policy 2017, 67, 640-651. [CrossRef]

9. Simon, J.; Machar, I.; Brus, J.; Pechanec, V. Combining a growth-simulation model with acoustic-wood tomography as a decision-support tool for adaptive management and conservation of forest ecosystems. Ecol. Inform. 2015, 30, 309-312. [CrossRef]

10. Sklenicka, P. Classification of farmland ownership fragmentation as a cause of land degradation: A review on typology, consequences, and remedies. Land Use Policy 2016, 57, 694-701. [CrossRef]

11. Macháček, J. Typology of Environmental Impacts of Artisanal and Small-Scale Mining in African Great Lakes Region. Sustainability 2019, 11, 3027. [CrossRef] 
12. Walker, L.R. Integration of the study of natural and anthropogenic disturbances using severity gradients. Austral Ecol. 2011, 36, 916-922. [CrossRef]

13. Van Andel, J.; Aronson, J. Restoration Ecology: The New Frontier; John Wiley \& Sons: Hoboken, NJ, USA, 2012.

14. Palmer, M.A.; Zedler, J.B.; Falk, D.A. Foundations of Restoration Ecology; Island Press: Washington, DC, USA, 2016.

15. Machar, I.; Vozenilek, V.; Simon, J.; Pechanec, V.; Brus, J.; Fulnecek, P.; Vitek, T. Joining of the historical research and future prediction as a support tool for the assessment of management strategy for European beech-dominated forests in protected areas. Nat. Conserv. 2017, 51-78. [CrossRef]

16. Clewell, A.F.; Aronson, J. Ecological Restoration: Principles, Values, and Structure of an Emerging Profession; Island Press: Washington, DC, USA, 2013.

17. Farber, S.; Costanza, R.; Childers, D.L.; Erickson, J.; Gross, K.; Grove, M.; Hopkinson, C.S.; Kahn, J.; Pincetl, S.; Troy, A. Linking ecology and economics for ecosystem management. Bioscience 2006, 56, 121-133. [CrossRef]

18. Sonter, L.J.; Ali, S.H.; Watson, J.E. Mining and biodiversity: Key issues and research needs in conservation science. Proc. R. Soc. B 2018, 285, 20181926. [CrossRef]

19. Larondelle, N.; Haase, D. Valuing post-mining landscapes using an ecosystem services approach-An example from Germany. Ecol. Indic. 2012, 18, 567-574. [CrossRef]

20. Li, X.; Stainback, G.; Barton, C.; Yang, J. Valuing the environmental benefits from reforestation on reclaimed surface mines in Appalachia. J. Am. Soc. Min. Reclam 2018, 7, 1-29.

21. Pechanec, V.; Machar, I.; Pohanka, T.; Opršal, Z.; Petrovič, F.; Švajda, J.; Šálek, L.; Chobot, K.; Filippovová, J.; Cudlín, P. Effectiveness of Natura 2000 system for habitat types protection: A case study from the Czech Republic. Nat. Conserv. 2018, 24, 21-41. [CrossRef]

22. Salekl, L.; Sivacioglu, A.; Topacoglu, O.; Zahradnile, D.; Jerabkoval, L.; Machar, I. Crowns of old remnant oak standards. Fresenius Environ. Bull. 2017, 26, 4023-4032.

23. Prach, K.; Tolvanen, A. How Can We Restore Biodiversity and Ecosystem Services in Mining and Industrial Sites; Springer: Berlin/Heidelberg, Germany, 2016.

24. Pitz, C.; Mahy, G.; Vermeulen, C.; Marlet, C.; Séleck, M. Developing biodiversity indicators on a stakeholders' opinions basis: The gypsum industry Key Performance Indicators framework. Environ. Sci. Pollut. Res. 2016, 23, 13661-13671. [CrossRef]

25. Brus, J.; Pechanec, V.; Machar, I. Depiction of uncertainty in the visually interpreted land cover data. Ecol. Inform. 2018, 47, 10-13. [CrossRef]

26. Whisenant, S. Repairing Damaged Wildlands: A Process-Orientated, Landscape-Scale Approach; Cambridge University Press: Cambridge, UK, 1999; Volume 1.

27. Helm, D.; Hepburn, C. The economic analysis of biodiversity: An assessment. Oxf. Rev. Econ. Policy 2012, 28, 1-21. [CrossRef]

28. Machar, I.; Kulhavy, A.; Sejak, J.; Pechanec, V. Conservation effectiveness and monetary value of floodplain forests habitats in the Czech Republic. Rep. For. Res. Zpravy Lesn. Vyzk. 2018, 63, 206-213.

29. Sejak, J.; Dejmal, I.; Petricek, V.; Cudlin, P.; Michal, I.; Cerny, K.; Kucera, T.; Vyskot, I.; Strejcek, J.; Cudlinova, E. Valuation and Pricing Biotopes of the Czech Republic; Czech Environmental Institute: Prague, Czech Republic, 2003.

30. Pechanec, V.; Machar, I.; Sterbova, L.; Prokopova, M.; Kilianova, H.; Chobot, K.; Cudlin, P. Monetary valuation of natural forest habitats in protected areas. Forests 2017, 8, 427. [CrossRef]

31. Deutscher, J.; Kupec, P.; Bajer, A. Biodiversity Action Plan as a means of sustaining ecological stability of opencast gravel mining sites. In Proceedings of the Public Recreation and Landscape Protection-With Nature Hand in Hand, Brno, Czech Republic, 1-3 May 2017.

32. Chytrý, M.; Kučera, T.; Kočí, M.; Grulich, V.; Lustyk, P. Katalog Biotopư České Republiky (Habitat Catalogue of the Czech Republic); Agency of Nature Conservation and Landscape Protection: Prague, Czech Republic, 2010; Volume 2, 445p.

33. Cílek, V.; Gremlica, T.; Lepšová, A.; Volf, O.; Vrabec, V.; Zavadil, V. Industriální Krajina a Její Přirozená Obnova: Právní Východiska a Rekultivační Metodika Oblastí Narušených Těžbou; Novela Bohemica: Prague, Czech Republic, 2013; 110p.

34. Pechanec, V.; Brus, J.; Kilianova, H.; Machar, I. Decision support tool for the evaluation of landscapes. Ecol. Inform. 2015, 30, 305-308. [CrossRef]

35. Prach, K. Ecological Restoration: Principles, Values, and Structure of an Emerging Profession. Restor. Ecol. 2008, 16, 730. [CrossRef] 
36. Christie, M.; Martin-López, B.; Church, A.; Siwicka, E.; Szymonczyk, P.; Sauterel, J.M. Understanding the diversity of values of "Nature's contributions to people": Insights from the IPBES Assessment of Europe and Central Asia. Sustain. Sci. 2019, 14, 1267-1282. [CrossRef]

37. Miko, L. Nature and landscape protection in the European context. In Ochrana Prirody a Krajiny v Ceske Republice, Vols I and II, Czech Republic; Machar, I., Drobilova, L., Eds.; Palacky University Olomouc: Olomouc, Czech Republic, 2012; Volume 1, pp. 43-49.

38. Lacková, E.; Kasovská, K.; Cmielová, L. Concept of reclamation management of the ash pond trinec (The Czech Republic). Int. Multidiscip. Sci. Geoconference Sgem Surv. Geol. Min. Ecol. Manag. 2012, 5, 185-192.

39. Šebelíková, L.; Ǩehounková, K.; Prach, K. Spontaneous revegetation vs. forestry reclamation in post-mining sand pits. Environ. Sci. Pollut. Res. 2016, 23, 13598-13605.

40. Walker, L.R.; Hölzel, N.; Marrs, R.; del Moral, R.; Prach, K. Optimization of intervention levels in ecological restoration. Appl. Veg. Sci. 2014, 17, 187-192. [CrossRef]

41. Prach, K.; Hobbs, R.J. Spontaneous succession versus technical reclamation in the restoration of disturbed sites. Restor. Ecol. 2008, 16, 363-366. [CrossRef]

42. Prach, K.; Pyšek, P. Using spontaneous succession for restoration of human-disturbed habitats: Experience from Central Europe. Ecol. Eng. 2001, 17, 55-62. [CrossRef]

43. De Steven, D. Experiments on mechanisms of tree establishment in old-field succession: Seedling emergence. Ecology 1991, 72, 1066-1075. [CrossRef]

44. Pyšek, P. Dominant species exchange during succession in reclaimed habitats: A case study from areas deforested by air pollution. For. Ecol. Manag. 1992, 54, 27-44. [CrossRef]

45. Řehounková, K.; Čížek, L.; Řehounek, J.; Šebelíková, L.; Tropek, R.; Lencová, K.; Bogusch, P.; Marhoul, P.; Máca, J. Additional disturbances as a beneficial tool for restoration of post-mining sites: A multi-taxa approach. Environ. Sci. Pollut. Res. 2016, 23, 13745-13753. [CrossRef]

46. Cudlín, P.; Prokopová, M.; Francírková, T.; Buresová, R. System NATURA 2000 utilization for purposes of biotope valuation. Ekológia 2005, 24, 52-68.

47. Lorne, F.T.; Dilling, P. Creating values for sustainability: Stakeholders engagement, incentive alignment, and value currency. Econ. Res. Int. 2012, 2012, 142910. [CrossRef]

48. Heneberg, P.; Bogusch, P.; Řehounek, J. Sandpits provide critical refuge for bees and wasps (Hymenoptera: Apocrita). J. Insect Conserv. 2013, 17, 473-490. [CrossRef]

49. Laurence, D. Mine closure and the community. Min. Environ. Manag. 2001, 9, 10-12. 